\title{
Cyberbezpieczeństwo a uczestnictwo MŚP w jednolitym rynku cyfrowym
}

\author{
Ciberseguridad y participación de las pymes \\ en el Mercado Único Digital
}

\author{
Jarosław Greser \\ Uniwersytet im. Adama Mickiewicza w Poznaniu
}

\section{Zagadnienia wprowadzające}

Wyzwania o charakterze geopolitycznym, wśród których można wskazać rosnącą rolę Chin, globalnym, takim jak zmiany klimatyczne, czy społecznym, jak starzenie się społeczeństwa, postawiły Unię Europejską przed koniecznością podjęcia inicjatyw mających na celu sprostanie im. Wytyczne polityczne sformułowane przez przewodniczącą Komisji Europejskiej Ursulę von der Leyen, priorytety postawione przez Parlament Europejski oraz program strategiczny Rady Europejskiej na lata 2019-2024 są spójną wizją działań dla UE będących odpowiedzią na zaistniałe problemy ${ }^{1}$. Opiera się ona na transformacji cyfrowej i ekologicznej, która ma objąć wszystkie aspekty gospodarcze i społeczne i doprowadzić do wzrostu konkurencyjności i dobrobytu Europy, suwerenności gospodarczej i technologicznej oraz odporności na wstrząsy zewnętrzne $e^{2}$. Założenie to jest precyzowane w kolejnych dokumentach takich jak Europejski Zielony $\mathrm{Lad}^{3}$ czy strategia „Kształtowanie cyfrowej przyszłości Europy"4 które wskazują, że cele te są współzależne i niemożliwe do osiągnięcia bez ścisłej współpracy na obu polach. Obrazuje to chociażby przykład roli sektora cyfrowego jako źródła rozwiązań w zakresie czystej technologii ${ }^{5}$ czy

\footnotetext{
${ }^{1}$ Komunikat Komisji do Parlamentu Europejskiego, Rady Europejskiej, Rady, Europejskiego Komitetu Ekonomiczno-Społecznego i Komitetu Regionów „Nowa strategia przemysłowa dla Europy”, COM(2020) 102 final, Bruksela, 10.03.2020, s. 1

${ }^{2}$ Komunikat Komisji do Parlamentu Europejskiego, Rady Europejskiej, Rady, Europejskiego Komitetu Ekonomiczno-Społecznego i Komitetu Regionów „Strategia MŚP na rzecz zrównoważonej i cyfrowej Europy”, $\operatorname{COM}(2020) 103$ final, Bruksela, 10.03.2020, s. 1.

${ }^{3}$ Komunikat Komisji do Parlamentu Europejskiego, Rady Europejskiej, Rady, Komitetu Ekonomiczno-Społecznego i Komitetu Regionów „Europejski Zielony Ład”, COM(2019) 640 final, Bruksela, 11.12.2019.

${ }^{4}$ Komunikat Komisji do Parlamentu Europejskiego, Rady Europejskiej, Rady, Komitetu Ekonomiczno-Społecznego i Komitetu Regionów „Kształtowanie cyfrowej przyszłości Europy”, COM(2020) 67 final, Bruksela, 19.2.2020.
}

${ }^{5}$ Komunikat Komisji „Nowa strategia ...”, s. 4. 
zwiększenie możliwości świadczenia usług na odległość, a tym samym zmniejszenie emisji gazu spowodowane ograniczaniem podróżowania ${ }^{6}$.

Szczególne znaczenie dla osiągnięcia tych planów ma rozwój jednolitego rynku cyfrowego, który uznaje się za punkt wyjścia do zachowania konkurencyjności UE i rozwoju w kierunku neutralności klimatycznej i przywództwa cyfrowego ${ }^{7}$. Trzeba zwrócić uwagę, że większość spośród podmiotów na nim operujących stanowią małe i średnie przedsiębiorstwa (MŚP), których liczbę szacuje się na 25 milionów ${ }^{8}$. Ich rola ma zasadnicze znaczenie we wprowadzaniu innowacji, nowych modeli biznesowych i rozwiązań, których skutkiem będzie realizacja założonych celów. Jednocześnie bariery występujące na tym rynku są najbardziej dotkliwe dla prowadzenia działalności gospodarczej przez te podmioty z powodu posiadania przez nie ograniczonych zasobów ${ }^{9}$ oraz trudności w ich uzupełnieniu, szczególnie w obszarze zasobów ludzkich, ze względu na brak specjalistów w obszarze ICT ${ }^{10}$.

Ponadto tworzenie i rozwój jednolitego rynku cyfrowego jest immanentnie związane $\mathrm{z}$ bezpieczeństwem działania na nim, które w odniesieniu do zagrożeń związanych $\mathrm{z}$ funkcjonowaniem $\mathrm{w}$ cyfrowym świecie nazywane jest cyberbezpieczeństwem. U źródeł tej tezy leży przekonanie, że im bardziej połączona staje się gospodarka i społeczeństwo, tym większa jest podatność na ataki i tym szersze są ich skutki, a pomimo transgranicznego charakteru zagrożeń kompetencje organów odpowiedzialnych za bezpieczeństwo i organów ścigania mają w głównej mierze charakter krajowy ${ }^{11}$. Obniża to zdolność do dokonania odpowiedniej reakcji, a w konsekwencji adekwatnej redukcji skutków ataku i ukarania osób za nie odpowiedzialnych. Jednocześnie na poziomie politycznym wskazuje się, że cyberzagrożenia są niebezpieczne dla demokracji i europejskich wartości. $Z$ tego powodu zagadnienia związane z cyberbezpieczeństwem wykroczyły poza wąsko pojmowaną problematykę techniczną i stały się niezbędne do realizacji celu politycznego, którym jest „Europe fit for the Digital Age”12.

${ }^{6}$ Komunikat Komisji do Parlamentu Europejskiego, Rady Europejskiej, Rady, Europejskiego Komitetu Ekonomiczno-Społecznego i Komitetu Regionów „2030 Digital Compass: the European way for the Digital Decade", $\operatorname{COM}(2021) 118$ final, Bruksela, 9.03.2021, s. 3.

${ }^{7}$ Komunikat Komisji do Parlamentu Europejskiego, Rady Europejskiej, Rady, Europejskiego Komitetu Ekonomiczno-Społecznego i Komitetu Regionów w sprawie określenia i usuwania barier na jednolitym rynku, $\operatorname{COM}(2020) 93$ final, Bruksela, 10.03.2020, s. 1.

${ }^{8}$ Komunikat Komisji „Strategia MŚP...”, s. 1.

${ }^{9}$ Komunikat Komisji w sprawie określenia... s. 3.

${ }^{10}$ Komunikat Komisji „2030 Digital Compass: ..., s. 4.

${ }^{11}$ Por. motyw 5 Rozporządzenia Parlamentu Europejskiego i Rady (UE) 2019/881 z dnia 17 kwietnia 2019 r. w sprawie ENISA (Agencji Unii Europejskiej ds. Cyberbezpieczeństwa) oraz certyfikacji cyberbezpieczeństwa w zakresie technologii informacyjno-komunikacyjnych oraz uchylenia rozporządzenia (UE) nr 526/2013 (akt o cyberbezpieczeństwie), Dz.Urz. UE L 151/15.

${ }^{12}$ A Union that strives for more. My agenda for Europe by candidate for President of the European Commission Ursula von der Leyen. Political Guidelines for the Next European Commission 2019-2024, https:// ec.europa.eu/commission/sites/ beta-political/files/political-guidelines- next-commission_en.pdf [dostęp: 10.03.2021]. 
W niniejszym rozdziale skupiono się na wskazaniu działań podejmowanych przez organy Unii Europejskiej w celu podniesienia poziomu cyberbezpieczeństwa małych i średnich przedsiębiorstw. Składa się on z trzech części. W pierwszej wskazano główne zagrożenia dla MŚP, których źródłem jest cyfryzacja. W drugiej scharakteryzowano pozaprawne działania UE w celu podniesienia poziomu cyberbezpieczeństwa, a w trzeciej przedstawiono regulacje prawne tworzące system cyberbezpieczeństwa, ze szczególnym uwzględnieniem planowanych zmian.

\section{Zarys zagrożeń $\mathrm{w}$ cyberprzestrzeni}

Rozważania dotyczące bezpieczeństwa w Internecie należy rozpoczać przywołaniem stwierdzenia byłego dyrektora FBI Robert Muellera, zgodnie z którym przedsiębiorstwa dzielą się na dwa typy: te, które padły ofiarą ataku, i te, które nimi się stanąa $^{13}$. Pogląd ten znajduje potwierdzenie empiryczne. Tytułem przykładu można wskazać atak na co najmniej 30000 organizacji przeprowadzony w Stanach Zjednoczonych w marcu 2021 roku $^{14}$ czy Soliorgate, który doprowadził do naruszenia systemów informacyjnych ponad 400 największych globalnych korporacji według listy Fortune $500^{15}$. Z raportów dotyczących polskich przedsiębiorstw wynika, że w 2017 roku 82\% z nich odnotowało przynajmniej jeden cyberincydent, a co czwarta firma zarejestrowała ich 10 lub więcej ${ }^{16}$. Jednocześnie trzeba zauważyć, że celem napastników są również instytucje unijne ${ }^{17}$ czy krajowe ograny władzy publicznej ${ }^{18}$, a walkę z nimi komplikuje różnorodność podmiotowa atakujących, do których zaliczają się przestępcy działający dla zysku, wywiady obcych państw, ekstremiś-

${ }^{13}$ R.S. Mueller, Speech, RSA Cyber Security Conference San Francisco, 1.03.2012, https://archives.fbi.gov/ archives/news/speeches/combating-threats-in-the-cyber-world-outsmarting-terrorists-hackers-and-spies [dostęp: 10.03.2021].

${ }^{14}$ Co najmniej 30000 organizacji w USA zhackowanych $w$ przeciagu ostatnich paru dni. Ogromna operacja cyberszpiegowska, SEKURAK, 5 marca 2021 r., https://sekurak.pl/co-najmniej-30-000-organizacji-w-usa-zhackowanych-w-przeciagu-ostatnich-paru-dni-ogromna-operacja-cyberszpiegowska/ [dostęp: 10.03.2021].

${ }^{15}$ Highly Evasive Attacker Leverages SolarWinds Supply Chain to Compromise Multiple Global Victims with SUNBURST Backdoor, Mandiant, 13 grudnia 2020 r., https://www.fireeye.com/blog/threat-research/2020/12/evasive-attacker-leverages-solarwinds-supply-chain-compromises-with-sunburst-backdoor. html [dostęp: 10.03.2021].

${ }^{16} 80$ proc. polskich firm doświadczyło przynajmniej jednego cyberataku, RyndekDomen.pl, 26 kwietnia 2018 r., https://rynekdomen.pl/2018/80- proc-polskich-firm-doswiadczylo- przynajmniej-jednego-cyberataku/ [dostęp: 10.03.2021].

${ }^{17}$ Cyberataki na Europejską Agencję Leków. Media: To byli chińscy i rosyjscy hakerzy, „Dziennik Gazeta Prawna”, 6 marca 2021 r., https://technologia.dziennik.pl/internet/artykuly/8113887, europejska-agencja-lekow-hakerzy-media-rosja-chiny.html [dostęp: 10.03.2021].

18 S. Palczewski, Zhakowano Urząd Marszałkowski w Krakowie, CyberDefence24, 11 lutego 2021 r., https://www.cyberdefence24.pl/zhakowano-urzad-marszalkowski-w-krakowie [dostęp: 10.03.2021]. 
ci czy hacktywiści działający dla dobra wspólnego ${ }^{19}$. Dodatkowym wskaźnikiem zwiększającym poziom zagrożenia jest przyspieszenie cyfryzacji wielu usług spowodowane pandemią COVID-1920. Zgodnie z danymi Międzynarodowego Związku Telekomunikacyjnego w czasie pandemii do ataku dochodzi co 39 sekund, a liczba e-maili wykorzystywanych do ataków wzrosła o $600 \%{ }^{21}$.

Zgodnie z systematyką wskazaną przez Włodzimierza Nowaka ataki na przedsiębiorstwa można podzielić na trzy grupy ${ }^{22}$ : ataki z użyciem szkodliwego oprogramowania, kradzieże tożsamości oraz ataki polegające na blokowaniu dostępu do usług. Ich skutki mogą dotknąć przedsiębiorstwo w różnych sferach i wywołać straty finansowe, reputacyjne lub skutkować stałym albo czasowym zaprzestaniem prowadzenia działalności operacyjnej. Ta ostatnia może prowadzić do znacznych zakłóceń w funkcjonowaniu społeczności, jak w przypadku ataku na infrastrukturę krytyczną taką jak systemy zaopatrzenia w wodę ${ }^{23}$ lub podmioty systemu opieki zdrowotnej ${ }^{24}$. Trzeba również zauważyć, że do takich skutków może doprowadzić nie tylko bezpośrednie działanie wobec przedsiębiorstwa, ale również atak na kluczowych podwykonawców lub usługodawców ${ }^{25}$.

Atak może mieć też konsekwencje w sferze prawnej. Szczególnym przypadkiem jest naruszenie przepisów o ochronie danych osobowych na terenie Unii Europejskiej regulowanych rozporządzeniem 2016/679 (RODO) ${ }^{26}$. Trzeba zauważyć, że w systemach informatycznych oprócz klasycznie rozumianych danych jak imię, nazwisko czy adresy zamieszkania często przetwarzane są również metadane

${ }^{19}$ J.P. Kesan, C.M. Hayes, Bugs in the Market: Creating a Legitimate, Transparent, and Vendor-focused Market for Software Vulnerabilities, „Arizona Law Review” 2016, no. 58, s. 769-770.

${ }^{20}$ Pospieszna cyfryzacja zwiększa ryzyko cyberataków. 4-krotny wzrost liczby incydentów, CyberDefence24, 3 grudnia 2020 r., https://www.cyberdefence24.pl/pospieszna-cyfryzacja-zwieksza-ryzyko-cyberatakow-4-krotny-wzrost-liczby-incydentow [dostęp: 10.03.2021].

${ }^{21}$ ONZ: podczas pandemii liczba złośliwych e-maili wzrosła o 600 proc., CyberDefence24, 25 maja $2020 \mathrm{r}$., https://www.cyberdefence24.pl/onz- podczas-pandemii-liczba-zlosliwych-e-maili-wzrosla-o-600-proc, [dostęp: 10.03.2021].

${ }^{22}$ W. Nowak, Specyfika zagrożeń w cyberprzestrzeni, w: Cyberbezpieczeństwo, red. C. Banasiński, M. Rojszczak, Warszawa 2020, s. 103.

${ }^{23}$ Amerykańska policja: hacker włamał się do systemu uzdatniania wody i wprowadził zmianę stężenia wodorotlenku sodu. 100 ppm -> 11100 ppm, SEKURAK, 8 lutego 2020 r., https://sekurak.pl/amerykanskapolicja-hacker-wlamal-sie-do-systemu-uzdatniania-wody- i-wprowadzil-zmiane-stezenia-wodorotlenku-sodu-100ppm-11100ppm/ [dostęp: 10.03.2021].

${ }^{24}$ Największy operator prywatnych szpitali w Europie zaatakowany, CyberDefence24, 7 maja 2020 r., https://www.cyberdefence24.pl/najwiekszy-operator-prywatnych-szpitali-w-europie-fresenius-zaatakowany-przez-hakerow [dostęp 10.03.2021]; 10 szpitali uderzonych przez Ransomware. Trzy przestały przyjmować pacjentów, SEKURAK, 2 października 2019 r., https://sekurak.pl/10-szpitali-uderzonych-przez-ransomware-trzy-przestaly-przyjmowac-pacjentow-us-australia/ [dostęp: 10.03.2021].

${ }^{25}$ Komunikat Komisji „2030 Digital Compass: ..., s. 7.

${ }^{26}$ Rozporządzenie Parlamentu Europejskiego i Rady (UE) 2016/679 z 27.04.2016 r. w sprawie ochrony osób fizycznych w związku z przetwarzaniem danych osobowych i w sprawie swobodnego przepływu takich danych oraz uchylenia dyrektywy 95/46/WE (ogólne rozporządzenie o ochronie danych), Dz. Urz. UE L 119, s. 1. 
i identyfikatory nadawane przez urządzenie takie jak adres IP. Zgodnie motywem 30 RODO i orzecznictwem TSUE mogą mieć one w pewnych sytuacjach charakter danych osobowych ${ }^{27}$. Jednocześnie zasada integralności i poufności wysłowiona w art. 5 ust. 1 lit. f RODO wskazuje, że dane należy chronić nie tylko przed niedozwolonym lub niezgodnym z prawem przetwarzaniem, ale również przypadkową utratą, zniszczeniem lub uszkodzeniem. Ponadto dodatkowe obowiązki w zakresie bezpieczeństwa danych są wskazane w art. 24 i 32-36 RODO. Daje to bardzo szeroki katalog sytuacji, w których przepisy tego aktu prawnego znajdują zastosowanie, a naruszenie reguł cyberbezpieczeństwa jest sankcjonowane przez krajowe organy ochrony danych. Tytułem przykładu można wskazać decyzje Prezesa Urzędu Ochrony Danych Osobowych, w których uznał on za naruszenie RODO brak testowania i oceny skuteczności środków technicznych i organizacyjnych wprowadzonych przez przedsiębiorstwo ${ }^{28}$ oraz brak aktualizacji oprogramowania używanego do przetwarzania danych osobowych ${ }^{29}$.

\section{Regulacje prawne mające na celu podniesienie cyberbezpieczeństwa na poziomie UE}

Niezależnie od wprowadzania przepisów regulujących cząstkowe komponenty cyberbezpieczeństwa, jak rozwiązania dotyczące ochrony danych osobowych, Unia Europejska podejmuje próby systemowej regulacji tego zagadnienia. W tym obszarze do najważniejszych należy zaliczyć Rozporządzenie 2019/881 ${ }^{30}$ zwane Aktem o cyberbezpieczeństwie oraz Dyrektywę 2016/1148 określaną w literaturze jako Dyrektywa NIS ${ }^{31}$.

Zgodnie $\mathrm{z}$ artykułem 1 ust. 1 rozporządzenia, jego zakres przedmiotowy obejmuje wyznaczenie celów i zadań Agencji Unii Europejskiej ds. Cyberbezpieczeństwa (ENISA) oraz ram ustanawiania europejskich programów certyfikacji cyberbezpieczeństwa. Oba te obszary mają wpływ na wzmocnienie bezpieczeństwa małych i średnich przedsiębiorstw. W zakresie działań ENISA należy wyróżnić zadania tego organu obejmujące edukację i tworzenie wiedzy dotyczącej cyberbezpieczeństwa.

${ }^{27}$ P. Litwiński, Pojęcie danych osobowych $w$ ogólnym rozporzadzeniu o ochronie danych osobowych glosa do wyroku Trybunału Sprawiedliwości z 19.10.2016 w sprawie c-582/14 Patrick Breyer, „Europejski Przegląd Sądowy” 2017, nr 5, s. 51-53.

${ }^{28}$ Decyzja Prezesa Urzędu Danych Osobowych z 11.02.2021, DKN.5130.2024.2020 https://www.uodo. gov.pl/decyzje/DKN.5130.2024.2020 [dostęp: 10.03.2021].

${ }^{29}$ Decyzja Prezesa Urzędu Danych Osobowych z 11.01.2021, DKN.5130.2815.2020, https://www.uodo. gov.pl/decyzje/DKN.5130.2815.2020 [dostęp: 10.03.2021].

${ }^{30}$ Rozporządzenie Parlamentu Europejskiego i Rady (UE) 2019/881 z dnia 17 kwietnia 2019 r. w sprawie ENISA.

${ }^{31}$ Dyrektywa Parlamentu Europejskiego i Rady (UE) 2016/1148 z dnia 6 lipca 2016 r. w sprawie środków na rzecz wysokiego wspólnego poziomu bezpieczeństwa sieci i systemów informatycznych na terytorium Unii, Dz.U rz. UE L 194/1. 
Pierwsze $\mathrm{z}$ nich jest normowane $\mathrm{w}$ artykule 10. Obejmuje ono zarówno działania własne agencji, jak i wsparcie państw członkowskich w sferze propagowania wiedzy na temat cyberbezpieczeństwa, w tym kampanie informacyjne i wymianę najlepszych praktyk.

Obowiązki w obszarze tworzenia wiedzy są regulowane w artykule 9. Nakłada on na ENISA obowiązek przeprowadzania analiz powstających technologii i przedstawiania tematycznych ocen dotyczących spodziewanego społecznego, prawnego, gospodarczego i regulacyjnego ich wpływu na cyberbezpieczeństwo oraz gromadzenia i analizowania publicznie dostępnych informacji dotyczących istotnych incydentów. Ponadto Agencja prowadzi portal, na którym gromadzi, systematyzuje i podaje do wiadomości publicznej informacje na temat cyberbezpieczeństwa. Kreowanie wiedzy może też zachodzić w czasie prac badawczo-rozwojowych, w których zgodnie z art. 11 lit. b i c rozporządzenia ENISA może brać udział zarówno jako beneficjent projektów mających na celu finasowanie badań, jak i podmiot uczestniczący $\mathrm{w}$ strategicznych badaniach $\mathrm{w}$ dziedzinie cyberbezpieczeństwa na poziomie unijnym.

Należy zauważyć, że działania ENISA są kierowane nie tylko do państw członkowskich. W zakresie działań edukacyjnych art. 10 lit. a Aktu o cyberbezpieczeństwie wprost wskazuje, że ich adresatami mają być „obywatele, organizacje i przedsiębiorstwa". Ta sama grupa jest odbiorcą sprawozdań z istotnych incydentów, o których mowa w art. 9 lit. e aktu, natomiast portal z informacjami o cyberbezpieczeństwie, o którym mowa w art. 9 lit. d tego rozporządzenia, jest udostępniany do informacji publicznej. W przypadku MŚP zasadniczą rolę będzie odgrywało promowanie cyberhigieny rozumianej zgodnie z motywem 8 rozporządzenia jako proste, rutynowe czynności, których wdrożenie i regularne wykonywanie minimalizuje narażenie na ryzyka związane z cyberzagrożeniami ${ }^{32}$. Ponadto dużym ułatwieniem, szczególnie dla przedsiębiorstw z sektora produkcji oprogramowania i urządzeń, będą rekomendacje dotyczące cyberbezpieczeństwa wskazujące najlepsze praktyki i uzupełniające lukę w wiedzy na ten temat ${ }^{33}$.

W zakresie europejskich ram certyfikacji cyberbezpieczeństwa rozporządzenie 2019/881 przewiduje powstanie systemu niezależnego od innych systemów

\footnotetext{
${ }^{32}$ M. Rojszczak, Praktyczne aspekty cyberbezpieczeństwa z perspektywy użytkownika, w: Cyberbezpieczeństwo, red. C. Banasiński, M. Rojszczak, Warszawa 2020, s. 39.

${ }^{33}$ IoT Security Standards Gap Analysis, ENISA, https://www.enisa.europa.eu/publications/iotsecurity-standards-gap-analysis, January 2019; Cyber security and resilience for Smart Hospitals, ENISA, 24 listopada 2016 r., https://www.enisa.europa.eu/publications/cyber-security-and-resilience-for-smart-hospitals [dostęp: 10.03.2021]; Dokumenty tego typu są regularnie publikowane przez agencje. Tytułem przykładu można wskazać: Good Practices for Security of IoT in the context of Smart Manufacturing, ENISA, 19 listopada 2018 r., https://www.enisa.europa.eu/publications/good-practices-for-security-of-iot; Industry 4.0 - Cybersecurity Challenges and Recommendations, ENISA, 20 maja 2019 r., https://www.enisa.europa.eu/publications/ industry-4-0-cybersecurity-challenges-and-recommendations [dostęp: 10.03.2021].
} 
certyfikacyjnych i nieuchylającego obowiązków z nich wynikających ${ }^{34}$. Zgodnie z motywem 13 zadaniem tego systemu jest potwierdzenie, że produkty ICT są zgodne $\mathrm{z}$ określonymi wymogami bezpieczeństwa mającymi na celu zabezpieczenia dostępności, autentyczności, integralności lub poufności przechowywanych, przekazywanych lub przetwarzanych danych bądź funkcji lub usług oferowanych lub dostępnych za pośrednictwem tych produktów, usług i procesów w trakcie ich całego cyklu życia. Definicja legalna zawarta w art. 2 pkt 12 określa „produkt ICT” jako element lub grupę elementów sieci lub systemów informatycznych. Jednocześnie pojęcie „systemu informatycznego" jest zdefiniowanie w art. 4 pkt 1 Dyrektywy NIS i zgodnie z nią obejmuje między innymi wszelkie urządzenia lub grupy wzajemnie połączonych lub powiązanych urządzeń, z których jedno lub większa ich liczba, wykonując program, dokonuje automatycznego przetwarzania danych cyfrowych. Na tej podstawie należy wnioskować, że zdecydowana większość urządzeń elektronicznych jest objęta tą definicją, a tym samym będzie mogła podlegać wskazanej certyfikacji.

Warto również zauważyć, że certyfikowane mogą być również usługi ICT rozumiane jako usługi polegające w pełni lub głównie na przekazywaniu, przechowywaniu, pobieraniu lub przetwarzaniu informacji za pośrednictwem sieci i systemów informatycznych oraz procesy ICT, które definiuje się jako zestaw czynności wykonywanych w celu projektowania, rozwijania, dostarczania lub utrzymywania produktów ICT lub usług ICT. Tym samym certyfikacją poza samym urządzeniem mogą być objęte wszystkie procesy związane $\mathrm{z}$ korzystaniem $\mathrm{z}$ niego. Zgodnie z art. 56 ust. 2 rozporządzenia 2019/881 certyfikacja cyberbezpieczeństwa jest dobrowolna, o ile prawo Unii lub prawo państwa członkowskiego nie stanowi inaczej. Obecnie nie ma przepisów nakazujących takie działanie, niemniej jednak art. 47 ust. 1 rozporządzenia przewiduje opublikowanie kroczącego programu prac na rzecz europejskich programów certyfikacji cyberbezpieczeństwa, które mają zawierać obszary poddawane regulacji w pierwszej kolejności. Zgodnie z art. 2 pkt 10 program taki obejmuje kompleksowy zbiór przepisów, wymogów technicznych, norm i procedur mających zastosowanie do certyfikacji lub oceny zgodności objętych zakresem danego programu produktów, usług i procesów ICT. Kryteriami przemawiającymi za uwzględnieniem danego programu w kroczącym programie prac są m.in. istnienie odpowiednich przepisów lub polityk Unii lub państwa członkowskiego oraz popyt na rynku.

Drugim dokumentem regulującym zagadnienia w zakresie cyberbezpieczeństwa jest dyrektywa 2016/1148 (Dyrektywa NIS). Celem tego aktu jest stworzenie ram prawnych umożliwiających powstanie krajowych systemów cyberbezpieczeństwa oraz sieci wymiany informacji i współpracy w tym zakresie pomiędzy państwami

${ }^{34}$ A. Żywicka, Uwarunkowania prawne bezpieczeństwa wyrobów medycznych. Certyfikacja wyrobów medycznych w świetle rozporzadzenia Parlamentu Europejskiego i Rady 2017/745 UE, w: Jakość w opiece medycznej. Teleporady, Internet Rzeczy, aplikacje śledzace, IP Boxy, red. K. Kokocińska, J. Greser, Warszawa 2021. 
UE. Jego wejście w życie uznaje się za przełomowy moment dla tworzenia ponadpaństwowego systemu ochrony, który między innymi miał wspierać rozwój jednolitego rynku cyfrowego. Jednocześnie jego funkcjonowanie w praktyce okazało się problematyczne, szczególnie dla MŚP. Jako przyczyny zaistnienia tego problemu wskazuje się między innymi rozbieżności w rozumieniu cyberbezpieczeństwa, ponieważ dyrektywa NIS nie zawiera definicji tego terminu ${ }^{35}$, oraz ograniczenia co do oceny poziomu odporności sieci i systemów informatycznych, a nie całego systemu teleinformatycznego ${ }^{36}$. Ponadto zaobserwowano zjawisko nadmiernie rygorystycznego wdrażania, które powoduje, że państwa członkowskie wykraczają poza zakres minimalnej harmonizacji nakładany dyrektywą, kreując różne obciążenia dla podmiotów rynkowych, co wpływa negatywnie na otoczenie biznesowe i działalność gospodarczą, w szczególności prowadzoną przez MŚP, i ma bezpośredni wpływ na funkcjonowanie rynku wewnętrznego, zwłaszcza na transgraniczne świadczenie usług $^{37}$. W związku z tym obszar ten został objęty programem sprawności i wydajności regulacyjnej (REFIT), którego celem jest ograniczenie obciążenia regulacyjnego dla właściwych organów oraz kosztów przestrzegania przepisów dla podmiotów publicznych i prywatnych.

Wynikiem prac Komisji jest wniosek legislacyjny z 16 grudnia 2020 roku mający na celu uchwalenie nowej dyrektywy roboczo nazywanej NIS $2^{38}$. Podkreśla się w nim, że zmiany mają na celu wsparcie w budowaniu gospodarki przygotowane na przyszłość oraz w realizacji celów strategicznych UE oraz są odpowiedzią Komisji na kryzys związany z COVID-19. Wskazano również, że przegląd dyrektywy 2016/1148 wykazał istnienie niskiego poziomu cyberodporności przedsiębiorstw działających w UE oraz niski poziom wspólnej orientacji sytuacyjnej i brak wspólnego reagowania kryzysowego. W związku z tym zgodnie z motywem 5 projektu dyrektywy NIS 2 akt ten ma na celu określenie minimalnych przepisów dotyczących funkcjonowania skoordynowanych ram regulacyjnych, ustanowienie mechanizmów skutecznej współpracy między odpowiedzialnymi organami w każdym państwie członkowskim, dokonanie aktualizacji wykazu sektorów i działań podlegających obowiązkom w zakresie cyberbezpieczeństwa oraz ustanowienie skutecznych środków naprawczych i sankcji, które są kluczowe dla skutecznego egzekwowania tych obowiązków.

Obowiązki nakładane przez dyrektywę NIS 2 można podzielić na trzy grupy. Pierwsza obejmuje przyjęcie krajowej strategii cyberbezpieczeństwa, wyznaczenie właściwych organów krajowych, pojedynczych punktów kontaktowych oraz zespo-

${ }^{35}$ G. Szpor, Nowelizacja siatki pojęciowej cyberbezpieczeństwa, „Monitor Prawniczy” 2020, nr 22, s. 1189.

${ }^{36} \mathrm{~K}$. Świtała, Bezpieczeństwo sieci i ustug w projekcie nowelizacji ustawy o Krajowym Systemie Cyberbezpieczeństwa, „Monitor Prawniczy” 2020, nr 23 s. 1240.

${ }^{37}$ Komunikat Komisji w sprawie określenia..., s. 13.

${ }^{38}$ Wniosek z dnia 16 grudnia 2020 r. „Dyrektywa Parlamentu Europejskiego i Rady w sprawie środków na rzecz wysokiego wspólnego poziomu cyberbezpieczeństwa na terytorium Unii, uchylająca dyrektywę (UE) 2016/1148", COM(2020) 823 final. 
łów reagowania na incydenty bezpieczeństwa komputerowego. Druga dotyczy określenia obowiązków w zakresie wymiany informacji na temat cyberbezpieczeństwa. Trzecia zawiera obowiązki związane z zarządzaniem ryzykiem w cyberprzestrzeni oraz zgłaszaniem incydentów przez określone podmioty. Trzeba zauważyć, że adresatem norm wynikających z dyrektywy są państwa członkowskie oraz wybrane podmioty publiczne i prywatne, które spełniają kryteria uznania ich za podmioty niezbędne albo podmioty istotne ${ }^{39}$. Jednocześnie zgodnie $\mathrm{z}$ art. 2 ust. 1 dyrektywa nie ma zastosowania do podmiotów kwalifikujących się jako mikroprzedsiębiorstwa, małe i średnie przedsiębiorstwa w rozumieniu zalecenia Komisji 2003/36 ${ }^{40}$. Prawodawca uzasadnia swój wybór w motywie 8, wskazując, że jednolite kryterium oparte na wielkości przedsiębiorstwa zwiększa pewność prawa w odniesieniu do podmiotów objętych obowiązkami wynikającymi z dyrektywy. Decyzję tę należy ocenić pozytywnie. Praktyka stosowania Dyrektywy NIS jednoznacznie wskazywała na różnorodną interpretację przesłanek do uznania przedsiębiorstwa za podmiot podlegający pod jej regulacje w poszczególnych państwach członkowskich. Wydaje się, że przyjęcie obecnego kryterium spowoduje zmniejszenie liczby takich przypadków.

Jednocześnie prawodawca zauważył, że specyfika cyberbezpieczeństwa nie może całkowicie przekreślać możliwości uznania MŚP za podmiot podlegający unormowaniom dyrektywy, szczególnie w sytuacji, gdy mają one zasadnicze znaczenie dla gospodarek lub społeczeństw państw członkowskich, a także konkretnych sektorów lub rodzajów usług. Zgodnie z art. 2 ust. 2 dyrektywy małe lub średnie przedsiębiorstwo będzie adresatem obowiązków z niej wynikających, jeżeli przedmiot jego działalności zawiera się $\mathrm{w}$ definicji podmiotów niezbędnych lub istotnych oraz równocześnie spełnia jedną z przesłanek wskazanych w tym przepisie, do których należą między innymi: prowadzenie działalności jako dostawca usług zaufania, świadczenie usług rejestracji domen najwyższego poziomu, bycie jedynym dostawcą danej usługi w państwie członkowskim, lub gdy zakłócenie świadczonych przez niego usług mogłoby mieć wpływ na porządek publiczny, bezpieczeństwo publiczne lub zdrowie publiczne albo prowadzić do powstania ryzyka

${ }^{39}$ Zgodnie z art. 4 pkt. 24 i 25 podmiot niezbędny oznacza każdy podmiot w rodzaju tego, który określono jako podmiot niezbędny w załączniku I, natomiast podmiot istotny oznacza każdy podmiot w rodzaju tego, który określono jako podmiot istotny w załączniku II. Wskazane załączniki zawierają rozszerzoną w stosunku do dyrektywy 2016/1148 listę podmiotów, na które nakładane są obowiązki, co zdaniem prawodawcy ma zapewnić całościowe uwzględnienie sektorów i usług mających istotne znaczenie dla kluczowych rodzajów działalności społecznej i gospodarczej w ramach rynku wewnętrznego. W przypadku podmiotów niezbędnych w stosunku do Dyrektywy NIS dodano między innymi infrastrukturę cyfrową, administrację publiczną i przestrzeń kosmiczną. W przypadku podmiotów istotnych usługi pocztowe i kurierskie, gospodarowanie odpadami, produkcję i dystrybucję chemikaliów, produkcję, przetwarzanie i dystrybucję żywności oraz sektor produkcji wyrobów medycznych, produktów komputerowych, elektronicznych i optycznych, sprzętu elektrycznego, maszyn, pojazdów samochodowych i innego sprzętu transportowego.

${ }^{40}$ Zalecenie Komisji 2003/361/WE z dnia 6 maja 2003 r. dotyczące definicji mikroprzedsiębiorstw oraz małych i średnich przedsiębiorstw, Dz. Urz. UE L 124/36. 
systemowego, w szczególności w sektorach, w których takie zakłócenie mogłoby mieć wpływ transgraniczny.

Należy zauważyć, że o ile państwa członkowskie same sporządzają wykaz MŚP podlegających przepisom dyrektywy, o tyle jest on przedkładany Komisji i weryfikowany nie rzadziej niż raz na dwa lata. Ponadto zgodnie z motywem 10 Komisja, działając wspólnie z Grupą Współpracy ${ }^{41}$, może sformułować wytyczne dotyczące wdrażania kryteriów mających zastosowanie do mikroprzedsiębiorstw i małych przedsiębiorstw. Rozwiązania te mają zapobiegać zjawisku nakładania nadmiernych obowiązków na te podmioty, których źródłem jest wskazywane powyżej nadmiernie rygorystyczne wdrażanie. Rozwiązanie to należy uznać za trafne, tym bardziej że dyrektywa NIS 2 ma być również aktem minimalnej harmonizacji, co rodzi zagrożenie przyjmowania różnych, bardziej restrykcyjnych i daleko idących rozwiązań w tym zakresie.

Jednocześnie prawodawca zdecydował się na inne rozwiązanie w zakresie relacji dyrektywy NIS 2 do unijnych sektorowych aktów prawnych niż obecnie funkcjonujące, które zakłada ich prymat nad ogólną regulacją ${ }^{42}$. Jako przykład można wskazać sektor łączności elektronicznej, który ma długą tradycję własnych regulacji w zakresie cyberbezpieczeństwa ${ }^{43}$, a zjawisko to ulegnie pogłębieniu po wejściu w życie Europejskiego kodeksu łączności elektronicznej ${ }^{44}$, który kompleksowo normuje kwestie cyberbezpieczeństwa w sektorze łączności elektronicznej ${ }^{45}$. W artykule 2 ust. 6 projektu dyrektywy NIS 2 zaproponowano rozwiązanie, że przepisów dyrektywy nie stosuje się tylko wówczas, gdy skutki wymogów wynikających z przepisów sektorowych są co najmniej równoważne skutkom obowiązków przewidzianych w tej dyrektywie. Jeżeli taka sytuacja nie występuje, to zastosowanie będą miały rozwiązania dyrektywy NIS 2, w tym w kwestiach dotyczących nadzoru. Trzeba jednak zauważyć, że będzie to miało zastosowanie tylko do podmiotów objętych regulacją tej dyrektywy. Dlatego jeżeli przepisy sektorowe nakładają na MŚP obowiązki o mniejszym zakresie niż NIS 2, a jednocześnie nie zachodzi żaden z wyjątków wskazanych w art. 2 ust. 2 dyrektywy, który pozwala taki podmiot objąć regulacjami tego aktu prawnego, należy uznać, że zastosowanie mają przepisy sektorowe.

${ }^{41}$ Zgodnie z art. 12 dyrektywy NIS 2 Grupa Współpracy jest ciałem powołanym do wspierania i ułatwiania strategicznej współpracy i wymiany informacji między państwami członkowskimi w obszarze stosowania dyrektywy. W jej skład wchodzą przedstawiciele państw członkowskich, Komisji i ENISA, a w charakterze obserwatora Europejska Służba Działań Zewnętrznych.

${ }^{42}$ S. Piątek, Obowiązki przedsiębiorców telekomunikacyjnych w zakresie cyberbezpieczeństwa, „Internetowy Kwartalnik Antymonopolowy i Regulacyjny” 2020, nr 2, s. 29.

${ }^{43}$ M. Rojszczak, Cyberbezpieczeństwo w łączności elektronicznej, w: Cyberbezpieczeństwo. Zarys wykładu, red. C. Banasiński, Warszawa 2018, s. 200 i nast.

${ }^{44}$ Dyrektywa Parlamentu Europejskiego i Rady (UE) 2018/1972 z dnia 11 grudnia 2018 r. ustanawiająca Europejski kodeks łączności elektronicznej, Dz. Urz. UE L321/36.

${ }^{45}$ S. Piątek, dz. cyt., s. 30. 


\section{Pozaprawne inicjatywy UE w celu podniesienia poziomu cyberbezpieczeństwa}

Na poziomie Unii Europejskiej istnieje konsensus co do tego, że nakładanie obowiązków prawnych nie jest wystarczające do osiągnięcia wysokiego poziomu cyberbezpieczeństwa w obrębie jednolitego rynku cyfrowego, tym bardziej że MŚP zgłaszają jako barierę brak odpowiedniej wiedzy eksperckiej w tym zakresie ${ }^{46}$. Wśród inicjatyw Komisji Europejskiej, które zmierzają do rozwiązania tego problemu można wskazać cztery grupy: edukacja, badania naukowe, wsparcie dla start-upów i tworzenie partnerstw europejskich.

W ramach działań w pierwszym ze wskazanych obszarów KE zobowiązała się do aktualizacji europejskiego programu na rzecz umiejętności, w tym paktu na rzecz umiejętności zawierającego specjalny komponent przeznaczony dla MŚP oraz opracowania intensywnych kursów umiejętności cyfrowych dla pracowników MŚP, szczególnie w obszarach sztucznej inteligencji, cyberbezpieczeństwa i blockchain ${ }^{47}$. Ponadto Komisja zaktualizuje oraz przedstawi wniosek dotyczący zalecenia Rady mającego na celu modernizację kształcenia i szkolenia zawodowego. W celu wsparcia osób starszych i tradycyjnych przedsiębiorstw ma zostać uruchomiony program „cyfrowi wolontariusze"48.

W obszarze badań celem Komisji jest rozwój technologii, które zostały uznane za kluczowe z perspektywy bezpieczeństwa i suwerenności technologicznej. W jej ramach wskazano robotykę, mikroelektronikę, infrastrukturę obliczeń wielkiej skali i chmury danych, blockchain, technologie kwantowe, fotonikę, biotechnologię przemysłową, biomedycynę, nanotechnologie, produkty lecznicze, materiały i technologie zaawansowane ${ }^{49}$. Szczególną rolę w tym systemie odgrywa program Horyzont Europa, którego cele zostały przyjęte przez Komisję, Parlament i Radę 11 grudnia $2020 \mathrm{roku}^{50}$. Program ten został wyposażony w budżet $\mathrm{w}$ wysokości około 95,5 mld euro na lata 2021-2027, a w jego ramach będą się mieściły działania Europejskiej Rady ds. Innowacji, która wspiera działania mające przełomowe znaczenie, ale zbyt ryzykowne dla prywatnych inwestorów. Na uwagę zasługuje to, że $70 \% \mathrm{z}$ ponad 10 mld euro zarezerwowanych na działania tego organu będzie przeznaczone dla małych i średnich przedsiębiorstw. Jednocześnie w opublikowanym w marcu 2021 roku planie strategicznym obszarów wspieranych przez program Horyzont Europa cyberbezpieczeństwo jest wskazane jako jeden z priorytetów, któ-

\footnotetext{
${ }^{46}$ Komunikat Komisji w sprawie określenia..., s. 19.

${ }^{47}$ Komunikat Komisji „Strategia MŚP..., s. 6.

${ }^{48}$ Tamże, s. 6-7.

${ }^{49}$ Komunikat Komisji „Nowa strategia..., s. 15.

${ }^{50}$ Komisja z zadowoleniem przyjmuje porozumienie polityczne w sprawie programu „Horyzont Europa”, następnego unijnego programu w zakresie badań naukowych i innowacji, Komisja Europejska, 10 grudnia 2020 r., https://ec.europa.eu/commission/presscorner/detail/pl/IP_20_2345 [dostęp: 10.03.2021].
} 
rego osiągnięcie ma skutkować stworzeniem bezpiecznego środowiska cyfrowego dla obywateli i przedsiębiorstw ${ }^{51}$.

W obszarze wsparcia dla start-upów trzeba zwrócić uwagę na trzy obszary. Pierwszym jest budowanie infrastruktury do świadczenia usług cyfrowych w standardzie $5 \mathrm{G}$ z uwzględnieniem wymogów w zakresie bezpieczeństwa, które są uznawane za priorytetowe. Podjęcie tych działań jest dla KE szczególnie istotne ze względu na ich znaczenie we wdrażaniu zielonych technologii ${ }^{52}$. Ponadto UE rozpoczęła prace na infrastrukturą komunikacji kwantowej, która w ciągu najbliższych 10 lat ma wprowadzić możliwość certyfikowanego szyfrowania kwantowego ${ }^{53}$. Trzeba zauważyć, że technologia ta znacznie wydajniej chroni informacje niż systemy używane obecnie ${ }^{54}$. Drugim obszarem jest wypracowanie unijnego standardu wspierania start-upów i zachęcanie państw członkowskich do wdrożenia jego praktyk na szczeblu lokalnym, regionalnym i krajowym oraz bezpośrednie wsparcie polegające na zwiększeniu liczby centrów innowacji cyfrowych oraz dalszy rozwój inicjatyw Startup Europe i Europejskiej Sieci Przedsiębiorczości ${ }^{55}$. Trzecim obszarem jest wsparcie w podejmowaniu działań na rynkach regulowanych, które z reguły są mało dostępne dla start-upów ze względu na wysoki próg wejścia ${ }^{56}$. Rozwiązaniem tego problemu jest tworzenie tzw. piaskownic regulacyjnych (regulatory sandbox), które umożliwiają przedsiębiorstwom wypróbowanie rozwiązań nieprzewidzianych w przepisach prawa, pozostając pod nadzorem organów regulacyjnych ${ }^{57}$. Dotychczas tego typu działania były podejmowane najczęściej w obszarze usług finansowych, w tym również w Polsce ${ }^{58}$, ale można znaleźć przykłady podobnych działań również $\mathrm{w}$ innych branżach takich jak energetyka ${ }^{59}$. Celem KE jest zachęcenie państw członkowskich do zwiększania zasięgu takich rozwiązań, co ma skutkować poszerzeniem dystrybucji innowacji, szczególnie w obszarach regulowanych.

Ostatnim obszarem wsparcia UE jest tworzenie partnerstw europejskich między Unią Europejską, państwami członkowskimi a przemysłem. Są to nowe inicjatywy,

${ }^{51}$ Horizon Europe Strategic Plan 2021-2024, Bruksela 2021, s. 59.

$525 G$ for Europes Digital and Green Recovery, EC, styczeń 2021 r., https://ec.europa.eu/digital-single-market/en/news/5g-europes-digital-and-green-recovery [dostęp: 10.03.2021].

${ }^{53}$ Komunikat Komisji „Nowa strategia...”, s. 15.

${ }^{54}$ A. Parakh, Providing variable levels of security in quantum cryptography, Proc. SPIE 10771, Quantum Communications and Quantum Imaging XVI, 107710R (18 September 2018), https://doi. org/10.1117/12.2323204.

${ }^{55}$ Komunikat Komisji „Strategia MŚP...”, s. 6-8.

${ }^{56}$ J.J. Goo, J.-Y. Heo, The Impact of the Regulatory Sandbox on the Fintech Industry, with a Discussion on the Relation between Regulatory Sandboxes and Open Innovation, „Journal of Open Innovation: Technology, Market, and Complexity" 2020, no. 2, s. 43.

${ }^{57}$ Komunikat Komisji „Strategia MŚP...”, s. 9.

${ }^{58} \mathrm{~K}$. Marchewka-Bartkowiak, Regulacyjne środowisko testowe (regulatory sandbox) - doświadczenia i perspektywy, „Studia Biura Analiz Sejmowych” 2019, nr 1, s. 61-75.

${ }^{59}$ E.C. van der Waal, A.M. Das, T. van der Schoor, Participatory Experimentation with Energy Law: Digging in a 'Regulatory Sandbox' for Local Energy Initiatives in the Netherlands, „Energies” 2020, nr 2, s. 458-479. 
których podstawą prawną mają być rozporządzenia wydane na podstawie art. 187 Traktatu o funkcjonowaniu Unii Europejskiej (TFUE) ${ }^{60}$. Ich celem jest przyspieszenie utworzenia i wykorzystywania nowych innowacyjnych rozwiązań w różnych sektorach poprzez mobilizację środków publicznych i prywatnych, szczególnie w zakresie ekologicznej i cyfrowej transformacji. Stroną partnerstwa mogą być ośrodki badawcze, szkoły wyższe, organizacje pozarządowe, podmioty publiczne na szczeblu lokalnym, regionalnym, krajowym lub międzynarodowym, a także przedsiębiorstwa, niezależnie od swojej formy i wielkości. Unia Europejska planuje zainwestowanie w te inicjatywy prawie 10 miliardów euro. W zakresie cyberbezpieczeństwa szczególne znacznie ma partnerstwo dotyczące kluczowych technologii cyfrowych, którego nadrzędnym celem jest wspieranie transformacji cyfrowej wszystkich sektorów gospodarczych i społecznych oraz Europejskiego Zielonego Ładu, a także Partnerstwo na rzecz inteligentnych sieci i usług, które ma się skupić na realizacji zadań wskazanych w strategii cyberbezpieczeństwa UE i unijnym zestawie narzędzi na potrzeby cyberbezpieczeństwa sieci $5 \mathrm{G}^{61}$.

\section{Podsumowanie}

Podstawowym środkiem, który ma prowadzić do realizacji priorytetów Unii Europejskiej, jest wykorzystanie potencjału cyfryzacji i technologii informacyjno-komunikacyjnych. Ze względu na ryzyko związane z korzystaniem z nich, pierwszoplanowa staje się problematyka cyberbezpieczeństwa. Ma ona szczególne znaczenie $\mathrm{w}$ odniesieniu do małych i średnich przedsiębiorstw, które z jednej strony stanowią trzon gospodarki unijnej, a $\mathrm{z}$ drugiej są relatywnie łatwiejszym celem ataków niż duże przedsiębiorstwa. Wynika to zarówno z braków dostępu do zasobów, jak i mniejszego poziomu świadomości wśród osób zatrudnionych w MŚP. Organy UE podjęły próbę rozwiązania tego wyzwania za pomocą instrumentów prawnych i pozaprawnych.

Wśród tych pierwszych kluczowe są regulacje mające doprowadzić do zbudowania systemu odporności na ataki na tym samym poziomie we wszystkich państwach członkowskich. Podstawową rolę w tym zakresie odgrywa dyrektywa NIS, która jednak ze względu na rozbieżność we wdrażaniu okazała się niewystarczająca do osiągnięcia tego celu, a jednocześnie stworzyła nowe bariery w funkcjonowaniu jednolitego rynku cyfrowego. Wniosek legislacyjny Komisji Europejskiej zmierzający do uchwalenia dyrektywy NIS 2 ma zniwelować zaobserwowane mankamenty oraz podnieść poziom bezpieczeństwa, szczególnie w sektorach dotychczas nie objętych

\footnotetext{
${ }^{60}$ Traktat o funkcjonowaniu Unii Europejskiej, Dz. Urz. UE C 326/47.

${ }^{61}$ UE ma ustanowić nowe partnerstwa europejskie i zainwestować prawie 10 mld euro $w$ ekologiczna i cyfrowa transformacje, komunikat prasowy z dnia 23 lutego 2021 r., https://ec.europa.eu/ commission/ presscorner/detail/pl/ ip_21_702 [dostęp: 10.03.2021].
} 
normowaniami. W propozycji Komisji zwraca uwagę rozszerzenie zakresu stosowania przepisów na sektor wytwórczy i przemysłowy oraz produkcję i dystrybucję żywności. Trzeba zauważyć, że w obu z nich operują liczne podmioty z sektora małych i średnich przedsiębiorstw, dla których nałożenie nowych obowiązków mogłoby się wiązać z dużym obciążeniem administracyjnym i finansowym. Dlatego należy podzielić stanowisko KE, która zasadniczo wyklucza objęcie MŚP tymi regulacjami, przedstawiając listę wyjątków, która będzie dotyczyła ograniczonej liczby podmiotów. Równie korzystnym rozwiązaniem wydaje się monitorowanie, jakiego rodzaju przedsiębiorstwa są uznane przez państwa członkowskie za podlegające wyjątkom, aby mieć pole do ewentualnej interwencji w tym zakresie.

Akt o cyberbezpieczeństwie jako drugi ze środków prawnych skupia się na tworzeniu instytucjonalnego środowiska do wspierania bezpieczeństwa w cyberprzestrzeni. Należy jednak zauważyć, że kompetencje Agencji Unii Europejskiej ds. Cyberbezpieczeństwa mogą mieć wpływ na polepszanie się sytuacji MŚP. Wynika to z przyznanych temu organowi kompetencji zarówno do prowadzenia działań edukacyjnych, jak i tworzenia ram w zakresie certyfikacji. W zakresie tego pierwszego obszaru istotne jest, że adresatami działań mogą być małe i średnie przedsiębiorstwa, które w ten sposób mogą zapełnić lukę kompetencyjną. Natomiast działania z zakresu certyfikacji pośrednio przyczynią się do poprawienia poziomu bezpieczeństwa MŚP poprzez możliwość wyboru urządzeń gwarantujących określony pułap zabezpieczeń bez konieczności prowadzenia analiz w tym zakresie.

Niezależnie od środków prawnych Unia Europejska przewiduje podjęcie inicjatyw edukacyjnych, wsparcie badań naukowych oraz środowiska start-upów, które mają prowadzić do bezpiecznego korzystania MŚP z jednolitego rynku cyfrowego. Należy uznać, że takie wsparcie jest zasadne i będzie znacznym wzmocnieniem sektora małych i średnich przedsiębiorstw.

\section{Resumen extenso / Streszczenie}

Ciberseguridad y participación de las pymes en el Mercado Único Digital

Los retos geopolíticos, entre los que se puede indicar el creciente rol de China, los retos globales, como los cambios climáticos, y los retos sociales, como el envejecimiento de la sociedad, han desafiado a la Unión Europea a tomar iniciativas con el fin de afrontarlos. Las indicaciones políticas formuladas por la Presidenta de la Comisión Europea, Ursula von der Leyen, las prioridades establecidas por el Parlamento Europeo y el Programa Estratégico 2019-2024 del Consejo Europeo constituyen una visión coherente de las acciones de la UE que son una respuesta a los problemas existentes. Se basa en una transformación digital y ecológica que deba abarcar todos los aspectos económicos y sociales y conducir a un aumento de la 
competitividad y la prosperidad de Europa, a la soberanía económica y tecnológica y a la capacidad de recuperación frente a los choques externos.

De especial importancia para la consecución de estos planes es el desarrollo de un Mercado Único Digital, que se considera el punto de partida para mantener la competitividad de la UE y evolucionar hacia la neutralidad climática y el liderazgo digital. Cabe señalar que la gran mayoría de sus operadores son pequeñas y medianas empresas (pymes), cuyo número se estima en 25 millones. Su papel tiene gran importancia para introducir la innovación, los nuevos modelos de negocio y las soluciones cuyo efecto será el cumplimiento de los objetivos propuestos. Al mismo tiempo, las barreras en este mercado son más dolorosas para el desarrollo de las actividades económicas para las entidades, debido a sus limitados recursos y a la dificultad para reponerlos.

Además, la creación y el desarrollo del Mercado Único Digital están inmanentemente relacionados con la seguridad de funcionar en él, que en relación con las amenazas que conlleva el funcionamiento en el mundo digital denominada la ciberseguridad. En la base de esta tesis está la creencia de que cuanto más interconectadas están la economía y la sociedad, mayor es la vulnerabilidad a los ataques y más amplio su impacto, y que, a pesar del carácter transfronterizo de las amenazas, las competencias de los organismos responsables por la seguridad y las fuerzas de orden son principalmente de carácter nacional. Esto reduce la capacidad de reaccionar adecuadamente $y$, en consecuencia, de reducir el impacto de un ataque y castigar a los responsables. Al mismo tiempo, a nivel político, las ciberamenazas se consideran una amenaza para la democracia y los valores europeos. Por esta razón, las cuestiones relacionadas con la ciberseguridad han ido más allá de un problema técnico estrechamente definido y se han convertido en indispensables para el cumplimiento del objetivo político de "Europe fit for the Digital Age" ["una Europa preparada para la Era Digital"].

En este capítulo me centraré en indicar las acciones que adoptan los organismos de la Unión Europea para aumentar el nivel de ciberseguridad de las pequeñas y medianas empresas. Se dividirá en tres partes. En la primera parte señalaré las principales amenazas para las pymes, cuya fuente es la digitalización. En la segunda parte caracterizaré las acciones extralegales de la UE para aumentar el nivel de ciberseguridad, mientras que en la tercera parte presentaré las disposiciones legales que crean el sistema de ciberseguridad, con especial énfasis en los cambios planeados.

Las consideraciones sobre la seguridad en internet se deben comenzar con la cita de la afirmación de ex director del FBI, Robert Mueller, según la cual las empresas se dividen en dos tipos: las que han sido víctimas de ataques y las que lo serán. Esta opinión se confirma empíricamente. Como ejemplo, podemos señalar el ataque a al menos 30.000 organizaciones llevado a cabo en EE.UU. en marzo de 2021 o el Soliorgate, que provocó una violación de los sistemas de información de más de 400 grandes corporaciones mundiales según la lista Fortune 500. Un indicador adicional 
que aumenta el nivel de amenaza es la aceleración de la digitalización de muchos servicios provocada por la pandemia COVID-19. Conforme con los datos de la Unión Internacional de Telecomunicaciones, durante la pandemia se produce un ataque cada 39 segundos y el número de correos electrónicos utilizados para los ataques aumentó un $600 \%$.

Independientemente de la introducción de normativas que regulen componentes parciales de la ciberseguridad, como las soluciones concernientes a la protección de datos personales, la Unión Europea está tratando de regular esta cuestión de forma sistémica. En este ámbito, destacan el Reglamento 2019/881 denominado Reglamento sobre la Ciberseguridad y la Directiva 2016/1148 denominada en la literatura como Directiva NIS [seguridad de redes y sistemas de información].

Conforme con el artículo 1 apartado 1 del Reglamento, su ámbito sustancial de aplicación incluye la fijación de los objetivos y tareas de la Agencia de la Unión Europea para la Ciberseguridad (ENISA) y el marco para el establecimiento de programas europeos de certificación de ciberseguridad. Ambas áreas tienen un impacto en el fortalecimiento de la seguridad de las pequeñas y medianas empresas. En el ámbito de las actividades de la ENISA, se deben distinguir las tareas de este organismo que incluyen la educación y la creación de conocimientos en materia de ciberseguridad. La primera está normalizada en el artículo 10. Incluye tanto las actividades propias de la agencia como el apoyo a los Estados miembros en el ámbito la promoción de la concienciación en materia de ciberseguridad, incluidas las campañas informativas y el intercambio de las mejores prácticas. Las responsabilidades en el ámbito de la creación de conocimientos se regulan en el artículo 9. En él se impone a ENISA la obligación de realizar los análisis de las tecnologías emergentes y presentar evaluaciones temáticas concernientes a un previsible impacto social, legal, económico y normativo en la ciberseguridad, y recopilar y analizar la información disponible públicamente sobre los incidentes importantes.

En el ámbito al marco europeo de certificación de la ciberseguridad, el Reglamento 2019/881 prevé la creación de un sistema independiente de otros sistemas de certificación y no exime de las obligaciones derivadas de los mismos. Según el artículo 56, apartado 2, del Reglamento 2019/881, la certificación de ciberseguridad es voluntaria, salvo que la legislación de la Unión o de los Estados miembros disponga otra cosa. Actualmente, no hay disposiciones que obliguen a ese tipo de acciones. El segundo documento que regula las cuestiones de la ciberseguridad es la Directiva 2016/1148 (Directiva NIS). El objetivo de este acto es crear un marco legal que facilite la creación de sistemas y redes nacionales de ciberseguridad para el intercambio de información y la cooperación en este ámbito entre los países de la UE. Su entrada en vigor se considera un momento histórico para la creación de un sistema de protección supranacional que, entre otras cosas, pretendía apoyar el desarrollo de un mercado único digital. Al mismo tiempo, su funcionamiento en la práctica resultó problemático, especialmente para las pymes. Por ello, el 16 de 
diciembre de 2020, la Comisión presentó una propuesta legislativa para adoptar una nueva directiva, denominada provisionalmente NIS 2.

El legislador ha determinado que las disposiciones de la directiva no se aplican a las entidades que se califican como microempresas, pequeñas o medianas empresas en el sentido de la Recomendación 2003/361 de la Comisión. Al mismo tiempo, el legislador ha notado que las especificidades de la ciberseguridad no pueden excluir por completo que las pymes se consideren unas entidades sujetas a las disposiciones de la directiva, especialmente en la situación cuando son de gran importancia para las economías o sociedades de los Estados miembros o para sectores o tipos de servicios concretos. Según el artículo 2 apartado 2 de la Directiva, las pequeñas o medianas empresas serán destinatario de las obligaciones resultantes de la Directiva, si su objeto de actividades está incluido en la definición de entidades imprescindibles o relevantes y, al mismo tiempo, cumple una de las premisas indicadas en esta disposición, que son, entre otras: realizar actividades como proveedor de servicios de confianza, prestar servicios de registro de dominios de primer nivel, ser el único proveedor de un servicio en un Estado miembro, o cuando la interrupción de los servicios prestados pueda afectar al orden público, a la seguridad pública o a la salud pública o provocar un riesgo sistémico, en particular en los sectores en los que dicha interferencia pueda tener un impacto transfronterizo.

Existe un consenso a nivel de la Unión Europea de que la imposición de obligaciones legales no es suficiente para lograr un alto nivel de ciberseguridad dentro del Mercado Único Digital, especialmente porque las pymes señalan como barrera la falta de conocimiento experto en esta área. Entre las iniciativas de la Comisión Europea que pretenden resolver este problema, se pueden identificar cuatro grupos: educación, investigación, apoyo a las start-ups y creación de asociaciones europeas.

Dentro de las acciones en el primero de los ámbitos indicados, la CE se ha comprometido a actualizar la agenda europea de capacidades, incluyendo un pacto de capacidades con un componente especial destinado para las pymes, y a desarrollar cursos intensivos de competencias digitales para los empleados de las pymes, especialmente en los ámbitos de la inteligencia artificial, la ciberseguridad y el blockchain.

En el ámbito de la investigación, la Comisión pretende desarrollar tecnologías que se han identificado como claves desde el punto de vista de la seguridad y la soberanía tecnológica. En su marco se ha indicado la robótica, la microelectrónica, la infraestructura de computación a gran escala y las nubes de datos, el blockchain, las tecnologías cuánticas, la fotónica, la biotecnología industrial, la biomedicina, las nanotecnologías, los productos médicos, los materiales y las tecnologías avanzadas. Horizonte Europa, cuyos objetivos fueron adoptados por la Comisión, el Parlamento y el Consejo el 11 de diciembre de 2020, desempeña un papel especial en este sistema.

En el ámbito del apoyo a las start-ups, hay que prestar atención a tres áreas. La primera es la construcción de infraestructura para prestar servicios digitales en el estándar 5G, teniendo en cuenta los requisitos de seguridad, que se consideran 
prioritarios. El último ámbito de apoyo de la UE es la creación de asociaciones europeas entre la Unión Europea, los Estados miembros y la industria. Se trata de nuevas iniciativas cuya base legal son los reglamentos dictados en virtud del artículo 187 del Tratado de Funcionamiento de la Unión Europea (TFUE). Su objetivo es acelerar la creación y explotación de nuevas soluciones innovadoras en diversos sectores mediante la movilización de recursos públicos y privados, en particular en el ámbito de la transformación ecológica y digital.

\section{Bibliografia}

5 G for Europe’s Digital and Green Recovery, EC, styczeń 2021 r., https://ec.europa.eu/digital-single-market/en/news/ 5g-europes-digital-and- green-recovery [dostęp: 10.03.2021].

10 szpitali uderzonych przez Ransomware. Trzy przestały przyjmować pacjentów, SEKURAK, 2 października 2019 r., https://sekurak.pl/ 10-szpitali- uderzonych-przez-ransomware- trzy-przestaly-przyjmowac-pacjentow- us-australia/ [dostęp: 10.03.2021].

80 proc. polskich firm doświadczyło przynajmniej jednego cyberataku, RyndekDomen.pl, 26 kwietnia 2018 r., https://rynekdomen.pl/2018/80-proc- polskich-firm-doswiadczylo-przynajmniej-jednego-cyberataku/ [dostęp: 10.03.2021].

A Union that strives for more. My agenda for Europe by candidate for President of the European Commission Ursula von der Leyen. Political Guidelines for the Next European Commission 2019-2024 https://ec.europa.eu/info/sites/ default/files/political-guidelines- next-commission_en_0.pdf [dostęp: 11.11.2021]

Amerykańska policja: hacker włamał się do systemu uzdatniania wody $i$ wprowadził zmianę stężenia wodorotlenku sodu. 100 ppm -> 11100 ppm, SEKURAK, 8 lutego 2020 r., https://sekurak.pl/ amerykanska- policja-hacker-wlamal-sie-do-systemu-uzdatniania- wody-i-wprowadzil-zmianestezenia-wodorotlenku-sodu-100ppm-11100ppm/ [dostęp: 10.03.2021].

Co najmniej 30000 organizacji w USA zhackowanych w przeciagu ostatnich paru dni. Ogromna operacja cyberszpiegowska, SEKURAK, 5 marca 2021, https://sekurak.pl/co-najmniej-30-000-organizacjiw-usa-zhackowanych-w-przeciagu-ostatnich-paru- dni-ogromna-operacja-cyberszpiegowska/ [dostęp: 10.03.2021].

Cyberataki na Europejską Agencję Leków. Media: To byli chińscy i rosyjscy hakerzy, „Dziennik Gazeta Prawna", 6 marca 2021 r., https://technologia.dziennik.pl/ internet/artykuly/8113887, europejska-agencja- lekow-hakerzy-media-rosja-chiny.html [dostęp: 10.03.2021].

Cyber security and resilience for Smart Hospitals, ENISA, 24 listopada 2016 r., https://www.enisa. europa.eu/ publications/cyber-security-and-resilience-for- smart-hospitals [dostęp: 10.03.2021].

Decyzja Prezesa Urzędu Danych Osobowych z 11.01.2021, DKN.5130.2815.2020, https://www.uodo. gov.pl/decyzje/ DKN.5130.2815.2020 [dostęp: 10.03.2021].

Decyzja Prezesa Urzędu Danych Osobowych z 11.02.2021, DKN.5130.2024.2020 https://www.uodo. gov.pl/decyzje/ DKN.5130.2024.2020 [dostęp: 10.03.2021].

Dyrektywa Parlamentu Europejskiego i Rady (UE) 2016/1148 z dnia 6 lipca 2016 r. w sprawie środków na rzecz wysokiego wspólnego poziomu bezpieczeństwa sieci i systemów informatycznych na terytorium Unii, Dz. Urz. UE L 194/1.

Dyrektywa Parlamentu Europejskiego i Rady (UE) 2018/1972 z dnia 11 grudnia 2018 r. ustanawiająca Europejski kodeks łączności elektronicznej, Dz. Urz. UE L321/36.

Goo J.J., Heo J.-Y., The Impact of the Regulatory Sandbox on the Fintech Industry, with a Discussion on the Relation between Regulatory Sandboxes and Open Innovation, „Journal of Open Innovation: Technology, Market, and Complexity" 2020, no. 2, s. 43-71. 
Good Practices for Security of IoT in the context of Smart Manufacturing, ENISA, 19 listopada 2018 r., https://www.enisa.europa.eu/publications/ good-practices-for-security-of-iot.

Highly Evasive Attacker Leverages SolarWinds Supply Chain to Compromise Multiple Global Victims with SUNBURST Backdoor, Mandiant, 13 grudnia 2020 r., https://www.fireeye.com/blog/ threat-research/2020/12/evasive-attacker- leverages-solarwinds-supply- chain-compromises-with- sunburst-backdoor.html [dostęp: 10.03.2021].

Horizon Europe Strategic Plan 2021-2024, Bruksela 2021, s. 59.

Industry 4.0 - Cybersecurity Challenges and Recommendations, ENISA, 20 maja 2019 r., https://www. enisa.europa.eu/publications/ industry-4-0-cybersecurity-challenges-and-recommendations [dostęp: 10.03.2021].

IoT Security Standards Gap Analysis, ENISA, https://www.enisa. europa.eu/publications/iotsecuritystandards-gap-analysis, January 2019.

Kesan J.P., Hayes C.M., Bugs in the Market: Creating a Legitimate, Transparent, and Vendor-focused Market for Software Vulnerabilities, „Arizona Law Review” 2016, no. 58.

Komisja z zadowoleniem przyjmuje porozumienie polityczne w sprawie programu „Horyzont Europa”, następnego unijnego programu w zakresie badań naukowych i innowacji, Komisja Europejska, 10 grudnia 2020 r., https://ec.europa.eu/ commission/presscorner/ detail/ pl/IP_20_2345 [dostęp: 10.03.2021].

Komunikat Komisji do Parlamentu Europejskiego, Rady Europejskiej, Rady, Komitetu Ekonomiczno-Społecznego i Komitetu Regionów „Europejski Zielony Ład” COM(2019) 640 final, Bruksela, 11.12.2019.

Komunikat Komisji do Parlamentu Europejskiego, Rady Europejskiej, Rady, Komitetu Ekonomiczno-Społecznego i Komitetu Regionów „Kształtowanie cyfrowej przyszłości Europy”, COM(2020) 67 final, Bruksela, 19.2.2020.

Komunikat Komisji do Parlamentu Europejskiego, Rady Europejskiej, Rady, Europejskiego Komitetu Ekonomiczno-Społecznego i Komitetu Regionów w sprawie określenia i usuwania barier na jednolitym rynku, COM(2020) 93 final, Bruksela, 10.03.2020.

Komunikat Komisji do Parlamentu Europejskiego, Rady Europejskiej, Rady, Europejskiego Komitetu Ekonomiczno-Społecznego i Komitetu Regionów „Nowa strategia przemysłowa dla Europy”, $\operatorname{COM}(2020) 102$ final, Bruksela, 10.03.2020.

Komunikat Komisji do Parlamentu Europejskiego, Rady Europejskiej, Rady, Europejskiego Komitetu Ekonomiczno-Społecznego i Komitetu Regionów „Strategia MŚP na rzecz zrównoważonej i cyfrowej Europy", COM(2020) 103 final, Bruksela, 10.03.2020.

Komunikat Komisji do Parlamentu Europejskiego, Rady Europejskiej, Rady, Komitetu Ekonomiczno-Społecznego i Komitetu Regionów „2030 Digital Compass: the European way for the Digital Decade", COM(2021) 118 final, Bruksela, 9.03.2021.

Litwiński P., Pojęcie danych osobowych w ogólnym rozporządzeniu o ochronie danych osobowych - glosa do wyroku Trybunatu Sprawiedliwości z 19.10.2016 w sprawie c-582/14 Patrick Breyer, „Europejski Przegląd Sądowy" 2017, nr 5, s. 51-53.

Marchewka-Bartkowiak K., Regulacyjne środowisko testowe (regulatory sandbox) - doświadczenia i perspektywy, „Studia Biura Analiz Sejmowych” 2019, nr 1, s. 61-75.

Mueller R.S., Speech, RSA Cyber Security Conference San Francisco, FBI, 1.03.2012, https://archives. fbi.gov/archives/news/ speeches/combating-threats-in- the-cyber-world-outsmarting-terroristshackers-and-spies [dostęp: 10.03.2021].

Największy operator prywatnych szpitali w Europie zaatakowany, CyberDefence24, 7 maja 2020 r., https://www.cyberdefence24.pl/ najwiekszy-operator- prywatnych-szpitali-w-europie-freseniuszaatakowany-przez-hakerow [dostęp 10.03.2021].

Nowak W., Specyfika zagrożeń w cyberprzestrzeni, w: Cyberbezpieczeństwo, red. C. Banasiński, M. Rojszczak, Warszawa 2020. 
ONZ: podczas pandemii liczba złośliwych e-maili wzrosła o 600 proc., CyberDefence24, 25 maja 2020 r., https://www.cyberdefence24.pl/ onz-podczas-pandemii-liczba-zlosliwych- e-maili-wzrosla-o600-proc [dostęp: 10.03.2021].

Palczewski S., Zhakowano Urząd Marszałkowski w Krakowie, CyberDefence14, 11 lutego 2021 r., https:// www.cyberdefence24.pl/ zhakowano-urzad- marszalkowski-w-krakowie [dostęp: 10.03.2021].

Piątek S., Obowiązki przedsiębiorców telekomunikacyjnych w zakresie cyberbezpieczeństwa, „Internetowy Kwartalnik Antymonopolowy i Regulacyjny" 2020, nr 2, s. 28-41.

Pospieszna cyfryzacja zwiększa ryzyko cyberataków. 4-krotny wzrost liczby incydentów, CyberDefence24, 3 grudnia 2020 r., https://www.cyberdefence24.pl/ pospieszna-cyfryzacja-zwieksza-ryzyko- cyberatakow-4-krotny-wzrost- liczby-incydentow [dostęp: 10.03.2021].

Rojszczak M., Cyberbezpieczeństwo w łączności elektronicznej, w: Cyberbezpieczeństwo. Zarys wykładu, red. C. Banasiński, Warszawa 2018.

Rojszczak M., Praktyczne aspekty cyberbezpieczeństwa z perspektywy u̇̇ytkownika, w: Cyberbezpieczeństwo, red. C. Banasiński, M. Rojszczak, Warszawa 2020.

Rozporządzenie Parlamentu Europejskiego i Rady (UE) 2019/881 z dnia 17 kwietnia 2019 r. w sprawie ENISA (Agencji Unii Europejskiej ds. Cyberbezpieczeństwa) oraz certyfikacji cyberbezpieczeństwa w zakresie technologii informacyjno-komunikacyjnych oraz uchylenia rozporządzenia (UE) nr 526/2013 (akt o cyberbezpieczeństwie), Dz. Urz. UE L 151/15.

Parakh A., Providing variable levels of security in quantum cryptography, Proc. SPIE 10771, Quantum Communications and Quantum Imaging XVI, 107710R (18 September 2018); https://doi. org/10.1117/12.2323204

Świtała K., Bezpieczeństwo sieci i usług w projekcie nowelizacji ustawy o Krajowym Systemie Cyberbezpieczeństwa, „Monitor Prawniczy” 2020, nr 23 s. 1239-1243.

Szpor G., Nowelizacja siatki pojęciowej cyberbezpieczeństwa, „Monitor Prawniczy” 2020, nr 22, s. 11891193.

Waal E.C. van der, Das A.M., Schoor T. van der, Participatory Experimentation with Energy Law: Digging in a 'Regulatory Sandbox' for Local Energy Initiatives in the Netherlands, „Energies” 2020, nr 2, s. 458-479.

Wniosek z dnia 16 grudnia 2020 r. „Dyrektywa Parlamentu Europejskiego i Rady w sprawie środków na rzecz wysokiego wspólnego poziomu cyberbezpieczeństwa na terytorium Unii, uchylająca dyrektywę (UE) 2016/1148", $\operatorname{COM}(2020) 823$ final

Zalecenie Komisji 2003/361/WE z dnia 6 maja 2003 r. dotyczące definicji mikroprzedsiębiorstw oraz małych i średnich przedsiębiorstw, Dz. Urz. UE L 124/36.

Żywicka A., Uwarunkowania prawne bezpieczeństwa wyrobów medycznych. Certyfikacja wyrobów medycznych $w$ świetle rozporzadzenia Parlamentu Europejskiego i Rady 2017/745 UE, w: Jakość w opiece medycznej. Teleporady, Internet Rzeczy, aplikacje śledzące, IP Boxy, red. K. Kokocińska, J. Greser, Warszawa 2021. 